\title{
Variscan exhumation of a subducted Paleozoic continental margin: The basal units of the Ordenes Complex, Galicia, NW Spain
}

\author{
José R. Martínez Catalán, ${ }^{1}$ Ricardo Arenas ${ }_{2}^{2}$ Florentino Díaz García ${ }^{3}$ \\ Francisco J. Rubio Pascual, ${ }^{4}$ Jacobo Abati, ${ }^{2}$ and Jorge Marquine $z^{3}$ \\ ${ }^{1}$ Departamento de Geologia, Universidad de Salamanca, Salamanca, Spain. \\ 2 Departamento de Petrologia y Geoquimica, Universidad Complutense Madrid, Spain. \\ ${ }^{3}$ Departamento de Geologia, Universidad de Oviedo, Oviedo. Spain. \\ ${ }^{4}$ nstituto Tecnológico Geominero de España, Madrid, Spain.
}

\begin{abstract}
A structural and metamorphic study was carried out in the basal units of the Ordenes Complex in Spain, thought to represent a subducted part of the Paleozoic margin of Gondwana. According to their metamorphic evolution, this part of the margin was subducted at the onset of the Variscan Orogeny, becoming part of an accretionary complex developed below a colliding element built previously. Variations in the PT conditions of the first high-pressure metamorphic event along the units indicate a polarity of the subduction to the west. Subsequent underthrusting of more continental material blocked the subduction and triggered the ascent and exhmation of the basal units, whereas the convergence continued. Recumbent folds and thru sts developed along with successive normal detachments. Compressional and extensional structures were synchronous or alternated in time and together induced the thinning and tapering of the orogenic wedge and its lateral spreading. The unroofing took place locally under an inverted temperature gradient caused by a detachment which carried a part of the hot mantle wedge above the subduction zone over the subducted units.
\end{abstract}

\section{Introduction}

One of the main problems posed by units with high pressure $(H P)$ metamorphism in orogenic belts is not the origin of such a metam orphi sm but the emplacement mechanisms bringing these units into parts of the crust not affected by the HP event and allowing the preservation of their parageneses.

The NW part of the Iberian Massif offers good conditions

for the study of such mechanisms because there exist several allochthonous complexes (Figure 1), the basal units of which underwent a HP event at the beginning of the Variscan Orogeny. These units exhibit similar characteristics regarding their lithology and tectono-metamorphic evolution and will be collectively referred to as the basal units.

The complexes crop out in synforms or structural basins formed in late stages of the orogenic cycle. The northern complexes are in Galicia (Spain) and the southern ones in Tras-os-Montes (Portugal). They consist of several allochthonous units of diverse provenance, with the exception of Malpica-Tui, in western Galicia, which is formed exclusively by the basal units.

The aim of this work is to unravel the sequence of events responsible for the HP metamorphism in rocks of continental origin and their emplacement in higher crustal levels. The study is centered in the Ordenes Compl ex (Figure 1), the largest and the one which better depiets the relationships between the basal units and the surrounding rocks. However references will $^{2}$ be made to the adjacent Malpica-Tui and Cabo Ortegal Complexes (Figure 2). The structural and thermobaric analyses show the complexities that the dynamic model of an orogenic wedge, which extends in its upper parts while convergence continues at depth [Platt, 1986), may show in a particular ease.

\section{Geological Setting}

\section{The Footwall Units}

The allochthonous complexes in the Iberian Peninsula rest upon a relatively coherent sequence [Farias et al.. 1987], up to $7 \mathrm{~km}$ thick, essentially metasedimentary, of Paleozoic and possibly Upper Proterozoic age which is often referred to as the parautochthon [Ribdro er al., 1990]. The latter is in turn tectonically emplaced above a set of metasediments and orthogneisses that will be called the relative autochthon. In spite of i ts name, the relative autochthon is strongly deformed, and recumbent folds and thrust sheets are common [Perez-Estaun et al, 1991]. Its sequences include Paleozoic shallow water elastics and carbonates deposited in a passive continental margin. Stratigraphic and faunistic similarities with northern African sequences suggest that this was the northern margin of the Paleozoic Gondwana [Blaise and Bouyx. J 980; Martinez Catalàn, 1990].

Three stratigraphic groups have been defined in the parautochthon of the Ordenes Complex: from bottom to top (Figure 3), the Santabaia, Nogueira, and Parai'io Groups (Marquinez Garcia, 1984; Farias et al., 1987). They consist of metapelites, quartz-feldspathic schists, and felsic igneous rocks. Carbonaceous pelites and quartzites are common in Nogueira, and amphibolites occur locally, as in the area of Cercio (Figure 4). Accordin g to correlations with the relative autochthon, the parautochthon may represent a more distal part of the same continental margin, as suggested by its tectonic position. 


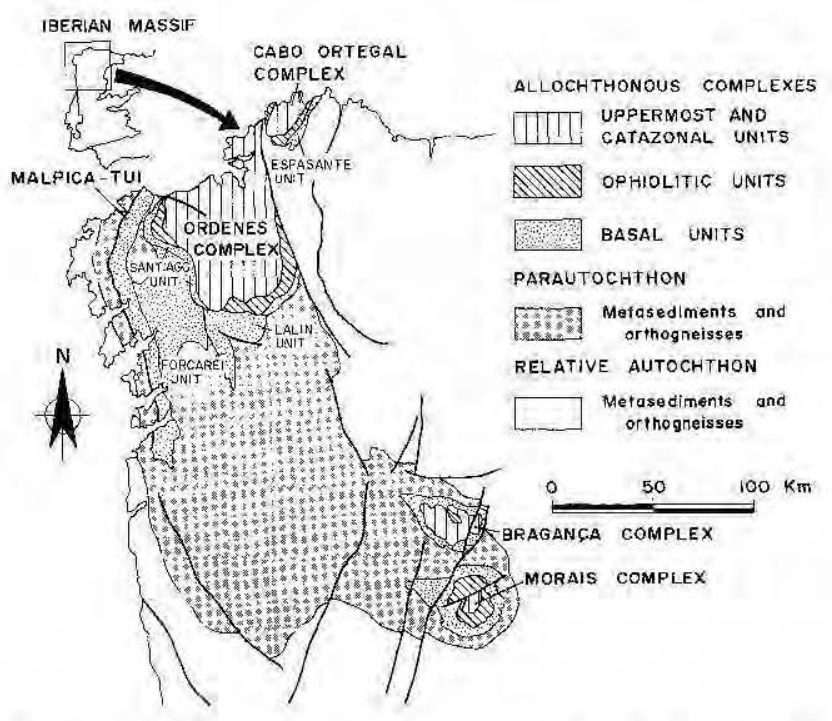

Figure 1. Sketch of the NW Iberian Massif showing the allochthonous complexes and the main sets of units.

\section{The Allochthonous Complexes}

For their description, we will loosely follow the sabdivisions made by Martínez Catalán et al. [1984], Arenas et al. [1986], and Díaz García [1992] and group the units of the Galician complexes into four sets (Figures 1 and 2): the basal, ophiolitic, catazonal, and uppermost units. Assuming that the ophiolites represent a collisional suture, the underlying basal units are interpreted as belonging to the margin of Gondwana, and the catazonal and uppermost units are considered as fartraveled terranes of doubtful provenance [Arenas et al., 1986; Martínez Catalán, 1990].

Basal units. They consist of monotonous pelitic and gresopelitic schists, commonly rich in albite porphyroblasts, and paragneisses, scarce quartzite horizons, felsic orthogneisses, biotitic augengneisses, and amphibolites.

In Ordenes, there exist three main units, known as the Lalín, Forcarei, and Santiago Units (Figures 2, 3, 4, and 5). They are considered parts of the same continuous sheet slightly broken by late orogenic events. The main orthogneissic bodies occur to the north of Lalín [Marquínez García, 1984] and in an elongated band, roughly $1 \mathrm{~km}$ thick, along the Santiago Unit (Figures 3, 4, and 5). All of them are considered to be of plutonic origin on textural grounds and viewed as extremely flattened and stretched granitoids. Small and very scarce mafic bodies in the Santiago orthogneiss have preserved eclogite parageneses.

Alternations of amphibolites are common as layers ranging in thickness from decimeters to a few meters. They are abundant in a band at the base of Lalín and Forcarei (Figure 3). Lenses of per-alkaline orthogneisses, a few meters thick, are also interbedded with the amphibolites [Hilgen, 1971].

A fourth unit outcrops in the west of Ordenes: the Agualada Unit [Díaz García, 1986]. It is a small tectonic slice, intercalated between the Santiago Unit and the ophiolites (Figures 5 and 6 , section E-E'), consisting of felsic orthogneisses similar to those of Santiago, migmatitic banded paragneisses, metabasites, and ultramafics. The higher metamorphic degree and the abundance of eclogites in the orthogneisses are the main differences with Santiago.

Malpica-Tui scems to be the continuation to the west of the basal units of Ordenes, from which it is separated by an antiform (Figure 6, section E-E'). The same rocks as described in Ordenes are common here [Gil Ibarguchi and Ortega Gironés, 1985], but relatively large bodies of alkaline to peralkaline orthogneisses are characteristic [Floor, 1966]. In the core of the antiform, the series are obscured by abundant Variscan granites and migmatites, but some lenticular orthogneisses and amphibolites south of Santa Comba (Figure 5) may represent the west and NW continuation of the Forcarei Unit. Accordingly, the basal units are thought to outerop also in the intermediate zone between Malpica-Tui and Ordenes (Figure 1).

In Cabo Ortegal, the Espasante Unit (Figures 1 and 2) was formerly related to the catazonal units [Arenas et al., 1986; Arenas, 1988]. However, its lithologic association and metamorphic evolution indicate a more probable link to the basal units. It consists of felsic orthogneisses, similar to those of Santiago, Lalín, and Agualada, amphibolites, retrograded eclogites, and scarce metasediments [Arenas, 1988].

Radiometrical dating of the orthogneisses yielded ages of 450-470 Ma by the Rb-Sr method in whole rock [V an Calsteren et al., 1979; García Garzón et al., 1981] and of 480 $\mathrm{Ma}$ by the U-Pb method in zircons [Santos Zalduegui et al., 1995]. They are interpreted as protolith ages and suggest that the sediments they intruded were at least Lower Ordovician. A palynological study [Fombella Blanco, 1984] revealed a Middle to Upper Ordovician age for the culminating metasediments of Malpica-Tui. The bimodal magmatism, the per-alkaline rocks, and the genetic relationship between the latter and the amphibolites [Marquinez García, 1984] suggest a rifting episode and the formation of a passive margin during the Ordovician [Arenas et al., 1986].

Ophiolitic units. This set includes several metaophiolitic units that are structurally above the basal units except in the east part of Cabo Ortegal, where an ophiolite underlies the basal Espasante Unit (Figure 2). This anomalous position is interpreted as due to an out-of-sequence thrust that crosscut the previously sfructured stack. The lower ophiolites of Cabo Ortegal consist of hasalts and hasaltic andesites, broken pillow-breccias and hyaloclastites, dykes and_other plutonic bodies of diabases, gabbros, plagiogranites, and highly serpentinized ultramafic rocks that show evidence of ocean-floor metamorphism overprinted by a dynamothermal epizonal event [Arenas, 1988].

The ophiolites overlying the basal units crop out in the marginal zone of the complexes of Ordenes and Cabo Ortegal. Several units outcrop discontinuously in different parts of both complexes. They may be grouped into two sets. The lower one is made up by mylonitic greenschist facies metabasites and metapelites and by small bodies of serpentinites. Mesozonal relics in the mafic rocks indicate a previous regional metamorphism of amphibolite facies. The unit of Vila de Cruces, in the south and SE of Ordenes (Figure 3 ), belongs to this set. 


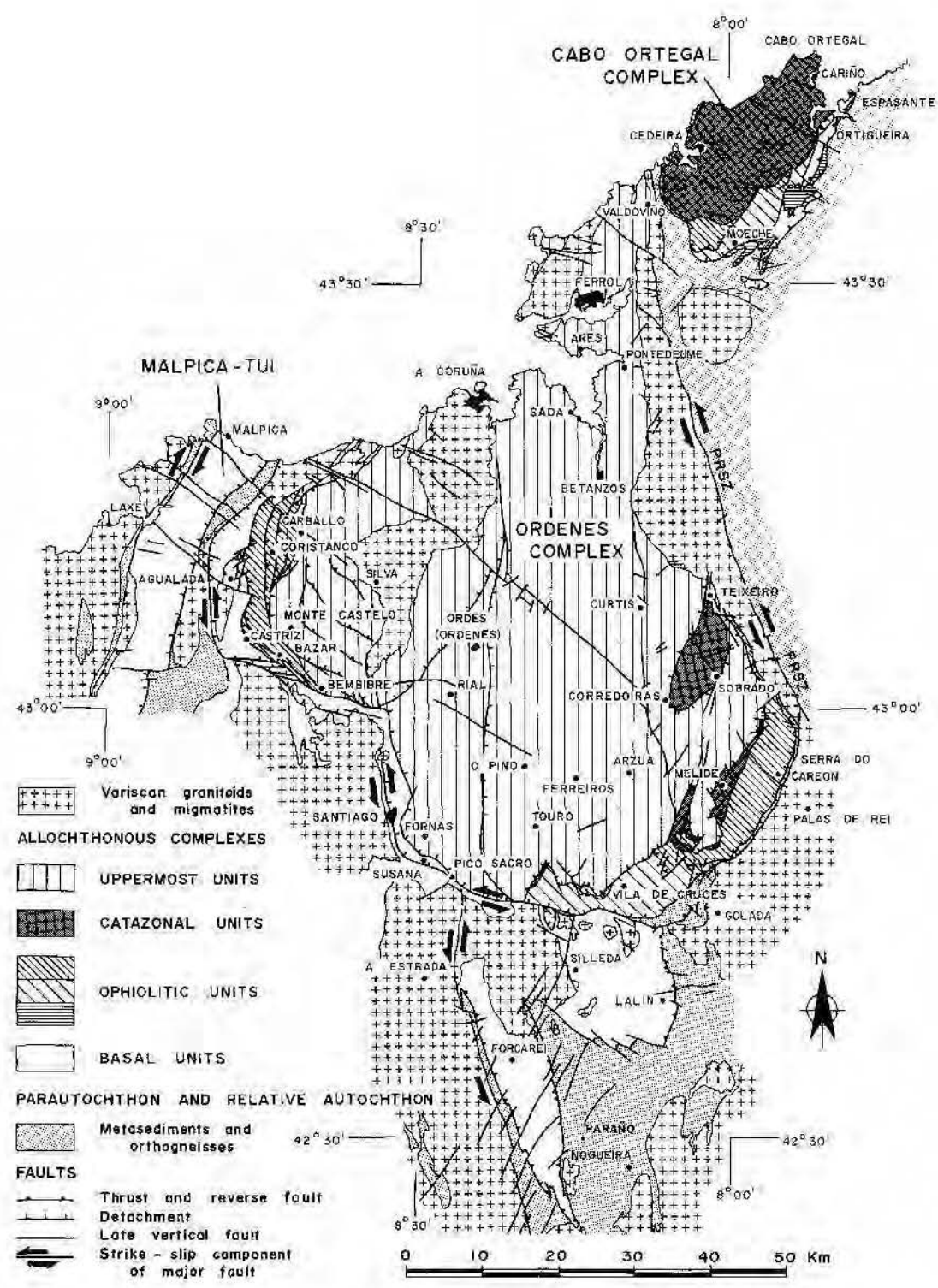

Figure 2. Geological map of the complexes of Ordenes, Cabo Ortegal and north of Malpica-Tui, showing the distribution of units and some important structural elements. Note that the heavy arrows in the detachments do not show their net slip but only the strike-slip components. The spelling of localities for this and other figures is in the Galician language. However, the Spanish name of Ordenes, instead of Ordes, has been retained for the whole complex. PRSZ is the Palas de Rei Shear Zone.

The upper ophiolites are represented in Ordenes by the units of Bazar, in the west, and Careón, in the SE (Figures 3 and 5). They consist of metagabbros, often pegmatitic, coronitic metagabbros, flaser amphibolites, amphibolites, and ultramafics [Warnaars, 1967; Maaskant, 1970; Díaz García, 1990] that reached the granulite facies in Bazar. The deformation is heterogeneous, with ductile shear zones bounding weakly deformed gabbros. Metamorphic conditions changed during shearing from the amphibolite to the greenschists facies.

A characteristic element is the Campo Marzo Ultramafic Slice, which outcrops in the core of a synform in the south of Ordenes (Figures 3,4, and 5). Other related ultramafic patches appear close to the west, surrounded by migmatites. The slice is considered a relic of the mantelic parts of the Careón ophiolite [Marquínez García, 1984].

Catazonal units. They consist of gneisses, supposedly of sedimentary origin, mafic rocks, and ultramafics. The characteristic rocks are metabasites, commonly garnetclinopyroxene granulites and eclogites, retrograded to the amphibolite facies. These units constitute more than half of Cabo Ortegal and form a small unit in the east of Ordenes, the Sobrado-Melide Unit (Figure 2).

The rare earth element (REE) spectrum of the eclogitic unit in Cabo Ortegal is characteristic of the oceanic crust [BernardGriffiths et al., 1985], and the main bodies of ultramafic rocks 


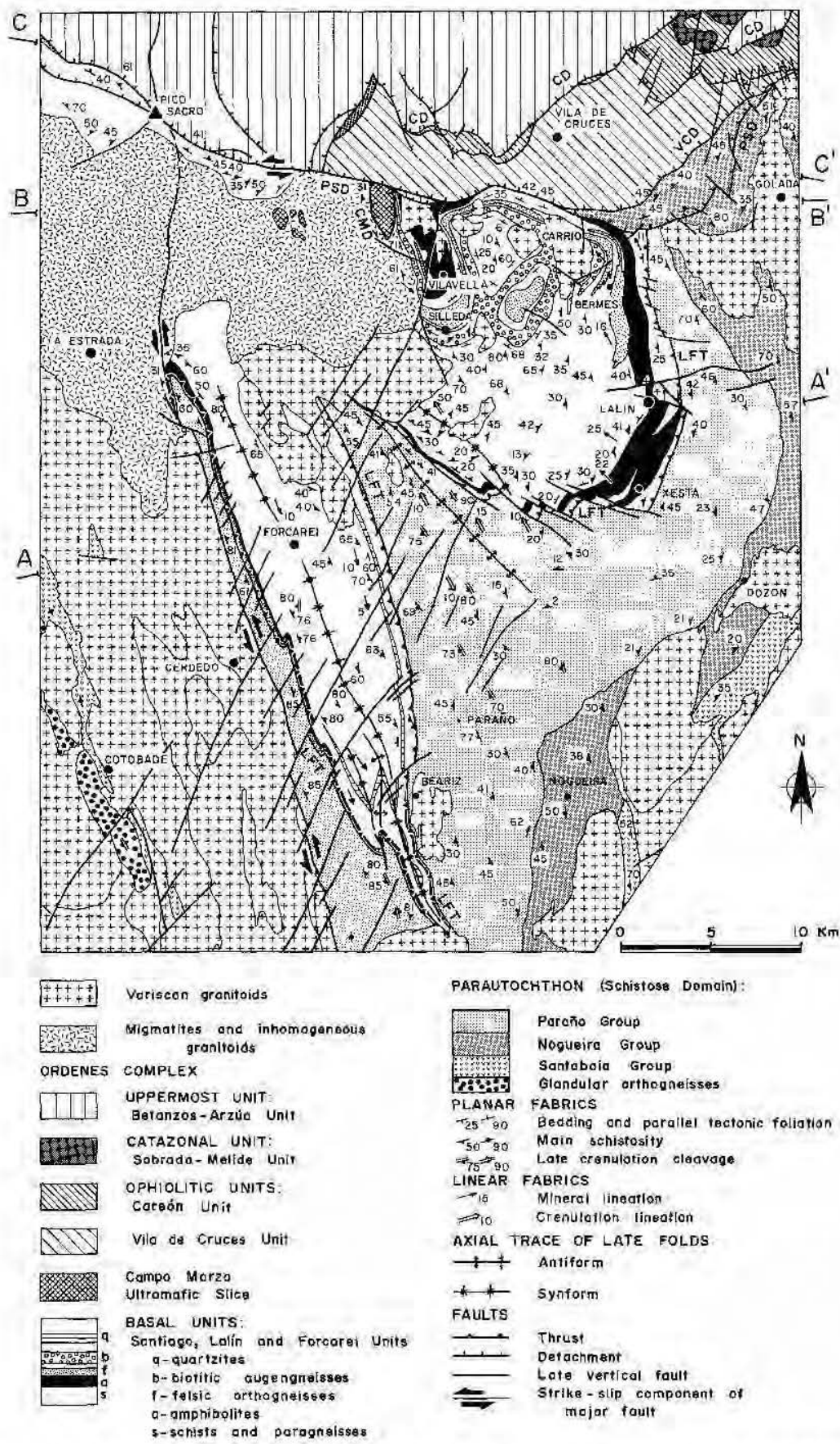

Figure 3. Geological map of the southern part of Ordenes showing the basal units of Lalín and Forcarei. LFT is the Lalín-Forcarei Thrust. Detachments are CD, Corredoiras; CMD, Campo Marzo; PSD, Pico Sacro: VCD, Vila de Cruces. Based on Marquínez García [1984].

are harzburgites of oceanic affinity [Girardeau and Gil Ibarguchi, 1991]. However, the apparent abundance of sediments points to a different origin. Island arc and back arc settings have been considered [Arenas et al., 1986, Peucat et al., 1990], though a rifted margin would also be possible. Several lower Paleozoic ages, between 480 and $490 \mathrm{Ma}$ [Peucat et al, 1990], previously interpreted as dating the HP-HT metamorphism, are now considered protolith ages [Schäfer et al., 1993], Data presented by the latter authors suggest also that the metasediments are younger than $507 \mathrm{Ma}$.

The metamorphic evolution included a former HP-HT granulitic/eclogitic metamorphism, followed by a decompressive episode of partial melting and then, successively, by a penetrative mylonitization in the 

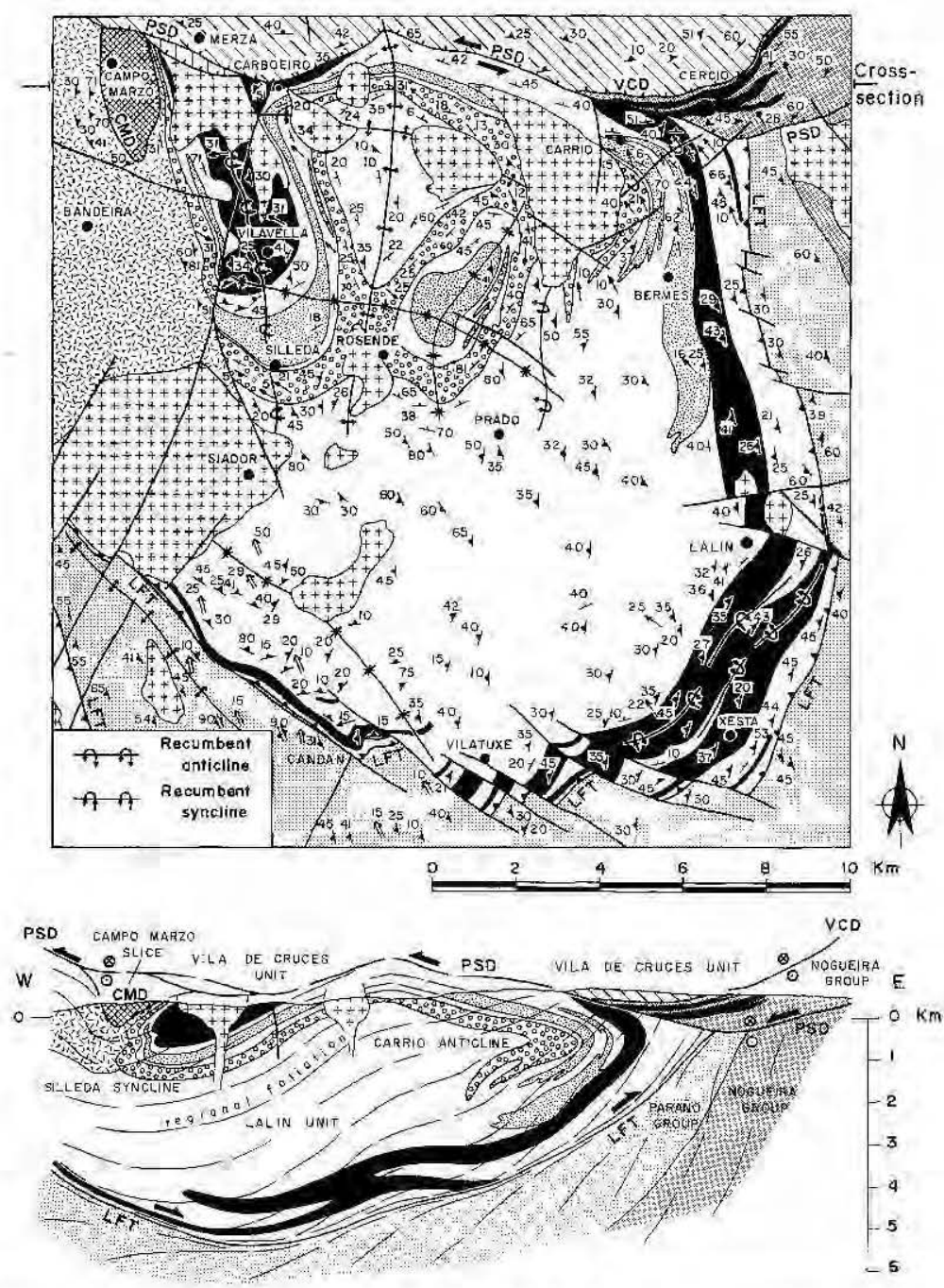

Figure 4. Detailed map and cross section of the Lalín Unit showing the recumbent folds, the transecting schistosity and the crosscutting relationships between the main detachments. Same legend and abbreviations as in Figure 3.

amphibolite facies, recumbent folding, and thrusting in the greenschists facies [Vogel, 1967; Marcos et al., 1984; Martinez Catalán and Arenas, 1992].

Uppermost units. Well exposed in the central part of Ordenes, they exist also in Morais, in Portugal. In Ordenes, the Betanzos-Arzúa Unit [Mariinez Catalán et al., 1984] consists of terrigenous metasediments, amphibolites, augengneisses, and gabbros. The gabbros and augengneisses are spatially related, suggesting contemporaneity. The augengneisses have been dated by the U-Pb method in zircons at 460-480 Ma [Kuijper, 1979], and a similar body in Morais yielded an age of $496 \mathrm{Ma}$ [Dallmeyer and Tucker, 1993].

The significance of these units is, as in the case of the catazonal ones, problematic, and similar origins may be proposed for both of them. What is relevant to our discussion is that they once formed part of a thick tectonic pile which reached the eclogite facies at depth and that they were emplaced on top of the ophiolitic units. The latter implies that an oceanic basin of unknown extent separated them from the continental margin represented by the basal units, the parautochthon, and the relative allochthon.

Metamorphism in Ordenes ranges from epizonal, in the upper parts of the unit, to catazonal in the lower. The limits between zones with different degree are often extensional faults [Díaz García, 1990], and a ductile subtractive fault, the Corredoiras Detachment (CD, Figure 3), separates this unit from the underlying catazonal Sobrado-Melide Unit [Martínez: Catalán and Arenas, 1992].

\section{Structure of the Basal Units}

Many of the present tectonic contacts in the Galician complexes are extensional detachments, and, in many cases, the units have been dismembered by the effects of extensional tectonics related to the gravitational collapse of the orogenic wedge. However, compressional recumbent folds and thrusts have been preserved in some areas and deserve special attention. 


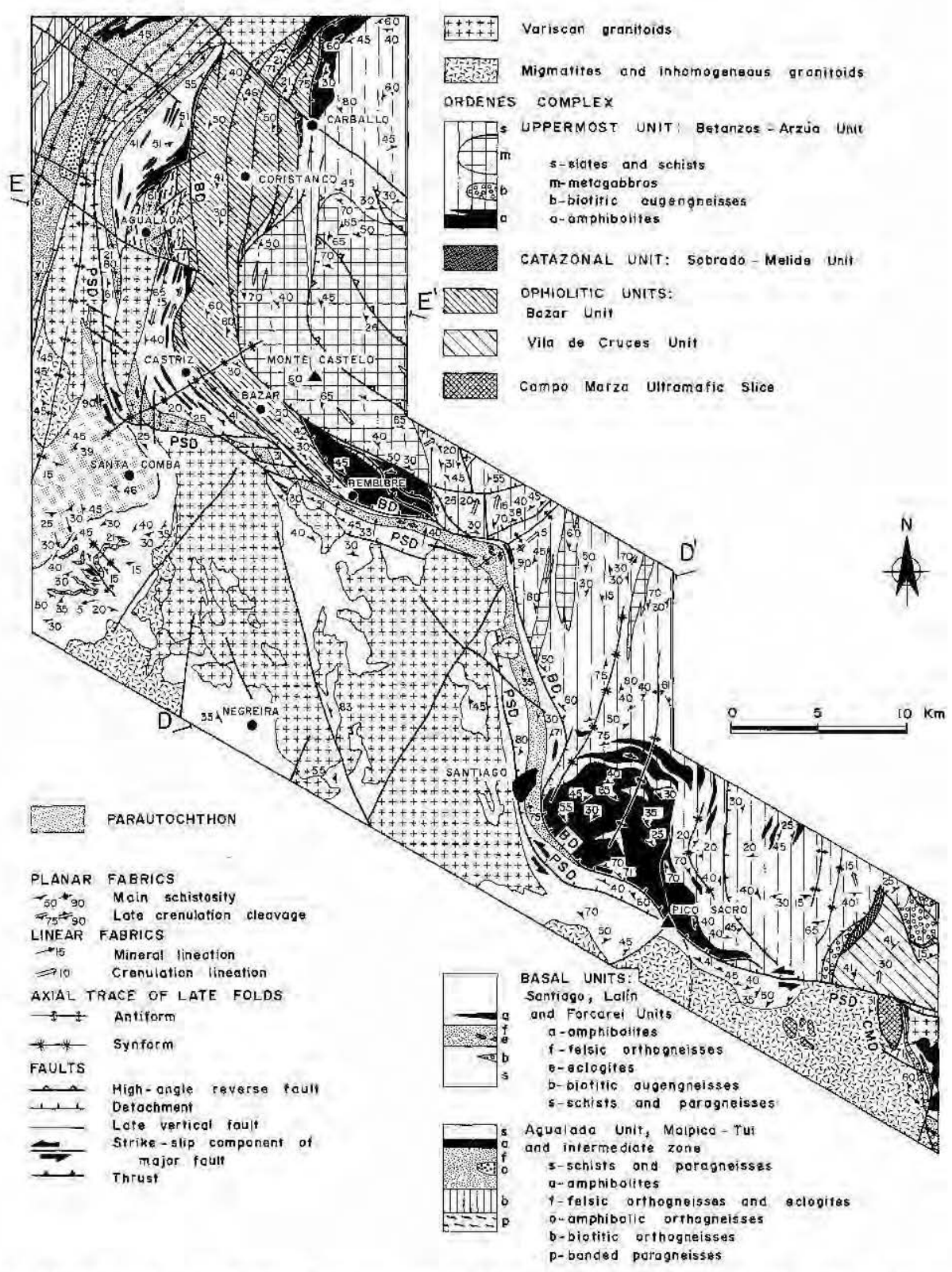

Figure 5. Geological map of the western part of Ordenes, including the basal units of Santiago and Agualada. Part of Malpica-Tui is also shown in the upper left corner, as well as the intermediate zone. Detachments are BD, Bembibre; CMD, Campo Marzo; PSD, Pico Sacro. Based on Díaz García [1990].

\section{FoId and Thrust Nappes}

The hinge zone of a major fold outcrops in the area of Carrio, in the NE of Lalín [Marquínez García, 1984]. The fold is a recumbent structure (Figure 4 ) interpreted as an anticline because the regional vergence is to the east in this part of the Variscan Belt and because its lower limb is affected by a ductile fault with eastward movement, the Lalin-Forcarei Thrust (LFT). The fold axis is oriented toughly NNW-SSE, plunging $10^{\circ}$ to $20^{\circ}$ to the NNW. Mapping of amphibolites suggests the existence of a pair of minor, tight folds in the reverse limb, south of Lalín (Figures 4 and 6). The inferred normal limb of the anticline is delineated by the felsic orthogneiss (Figure 4) and can be followed until the locality of Silleda, where a syncline occurs. However, the similarity between the orthogneiss of Santiago, north of the Pico Sacro Detachment (PSD), and Lalín, as well as the abundance of amphibolites intercalated in the metasediments above the orthogneiss and not below, suggests that the Silleda fold is a relatively minor structure that may be followed to the west by one or several folds hidden by the PSD and that the Santiago Unit is the normal limb of the Carrio Anticline (Figute 6, section D-D').

The regional foliation in Lalín forms an angle of $10^{\circ}-20^{\circ}$ with the lithological banding. It transects the reverse and normal limbs of the Carrio Anticline and, originally, dipped $10^{\circ}-20^{\circ}$ steeper to the west than both limbs. The foliation 


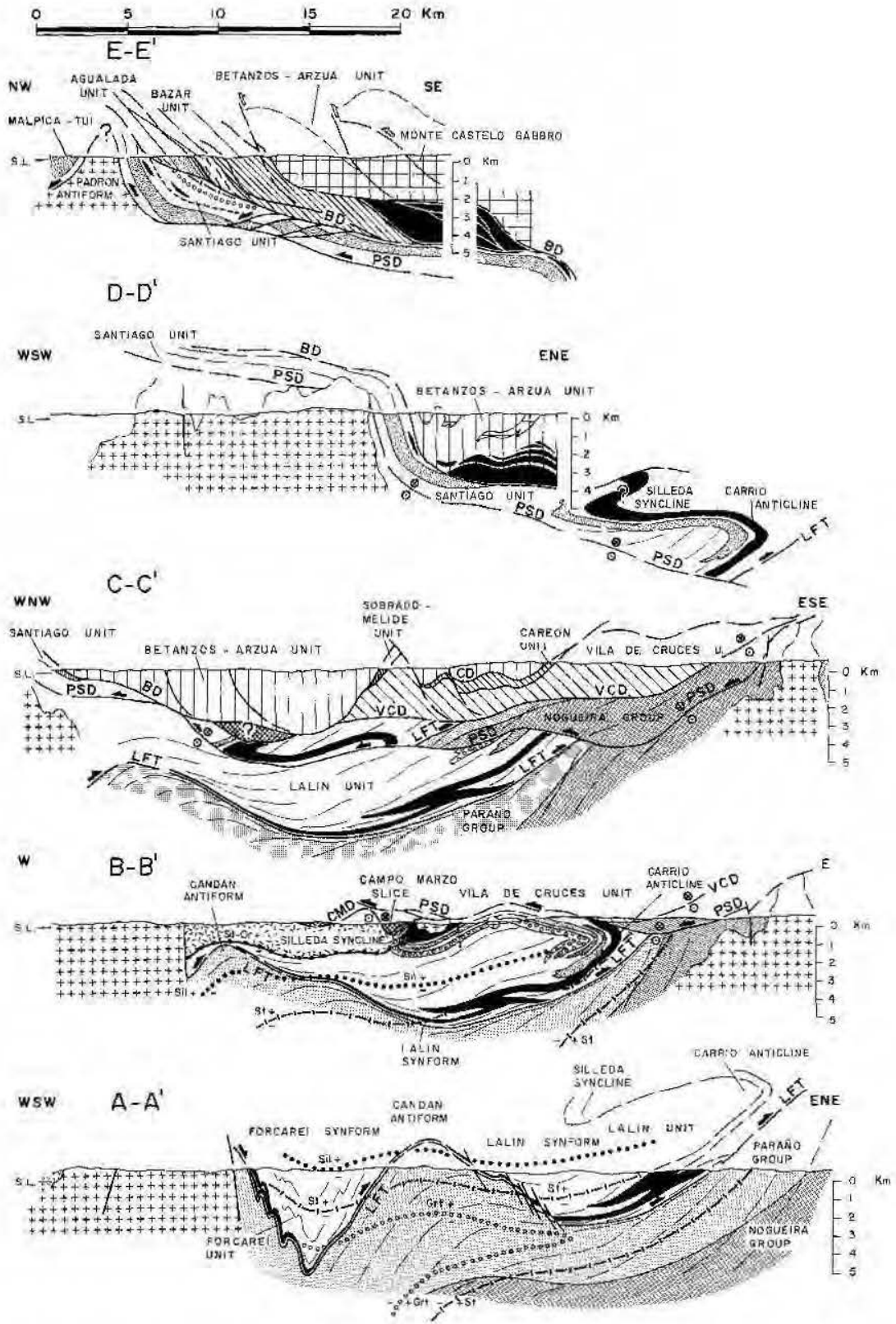

Figure 6. Geological sections across the basal units depicting the main structures and the relationships with the other units. See Figures 3 and 5 for location and legend. For the isogtads in sections A-A', B-B' and E-E', see legend of Figure 7. The components of movement normal to the section are indicated by circles with a dot or a cross, indicating movement toward the reader or opposite, respectively.

rotates in the basal part of Lalín, becoming progressively parallel to the LFT (Figure 4). It seems probable that folds and foliation were developed in a wide regional shear zone. Their progressive reorientation close to the narrow shear zone defining the LFT points to a related origin. Taking the geometrical relationships between the foliation and the LFT as a mega S-C structure, the sense of shear was toward the east.

In the hinge zone of the Carrio and Silleda folds, a previous foliation may be seen parallel to the bedding and folded with it. In the amphibolites and orthogneisses, the overprinting of the previous fabric by the transecting one results in a mineral lineation parallel to the fold axes. The NW-SE mineral lineation often found in Lalín (Figures 3 and 4) is consequently interpreted as an intersection lineation. Both the regional and the previous foliations are generally mediumgrained, and, in the schists, both fabrics may be seen in thin section. An older fine-grained cleavage has been preserved as oriented microinclusions in albite porphyroblasts grown during the development of the later fabrics [Arenas et al., 1995].

The LFT is a 40 to 80 -m-thick shear zone with mylonites and ultramylonites, which separates the Lalín Unit from the 
parautochthonous. Rocks of both units are mylonitized. The mapped amphibolites of Lalín, which have a thickness of around $500 \mathrm{~m}$ in the north and east, become progressively narrow to the south, as they approach the shear zone and follow on, thin and discontinuous, in the Forcarei Unit, to the west. The amphibolites, commonly medium-grained, recrystallized to fine-grained rocks in the shear zone, and, in the eastern part, they are sometimes very fine-grained amphibolitic schists. Thin layers of mylonitic quartzite, intercalated in the Paraño Group, were considered to mark the thrust plane by Hilgen [1971]. They have an elongated texture and show a stretching lineation variably oriented due to late folding. The E-W orientation in the hinge zone of the open Lalín synform is probably close to the original direction. Quartz $\mathrm{c}$ axis fabrics are of the single-girdle type [Díaz Garcia, 1993].

The same relationship described in Lalín between the main schistosity and the LFT is seen in its relative autochthon: the main schistosity in the Paraño Group dipped originally some $10^{\circ}-30^{\circ}$ to the west more than the LFT (Figures 4 and 6 ). The regional foliation in Paraño is a crenulation cleavage less evolved than in Lalín and Forcarei. The quartzite textures are less elongated than in the mylonite, and the quartz $c$ axis fabrics do not show clear girdles [Díaz García, 1993].

The Agualada Unit, in Ordenes, and the Espasante Unit, in Cabo Ortegal, are quite similar in lithology and metamorphic evolution. An important thrust explains the structural position of Agualada and its higher metamorphic degree in relation to the underlying Santiago Unit [Diaz Garcia, 1986]. Discontinuous lenses of ultramafics at its base indicate that the mantle was involved in the thrusting. The internal structure is homoclinal, dipping to the east, and includes a narrow band of ultramafics overlain by amphibolites, which is considered as a subordinate thrust separating two subunits. The fact that these types of unit appear so scarcely represented in the complexes and so separated, together with their lensoidal character, suggests that they formed part of a formerly continuous unit that has been thoroughly dispersed.

\section{Detachments and Late Folds}

Several generations of detachments affected the nappe pile, along with three generations of upright folds. Wc will deal only with the particular structures concerning the basal units.

One of the flat-lying faults, the Campo Marzo Detachment (CMD) in the NW of Lalín (Figures 3, 4, and 6, section B-B'), carried a sheet of ultramafics over the Lalín Unit, inducing heating from above and giving way to an inverted metamorphic gradient. Though the preserved extent of the ultramafic slice is limited, the inverted metamorphism can be followed in most of the Forcarei and Lalin Units (Figure 7). The associated mylonitization affects the reverse limb of the Silleda Syncline (Figure 4), but heating was contemporaneous with the late stages of formation of the regional foliation. Consequently, the CMD postdated the nucleation of the recumbent folds but was partially contemporaneous with the transecting foliation. The stretching lineations and kinematic criteria in mylonites east of Campo Marzo indicate a top to the north sense of shear.

The Bembibre Detachment (BD), in the west of Ordenes (Figure 5), occupies a position similar to the CMD, separating

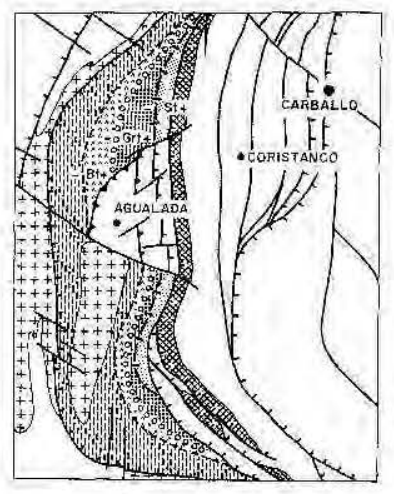

METAMORPHIC ZONES
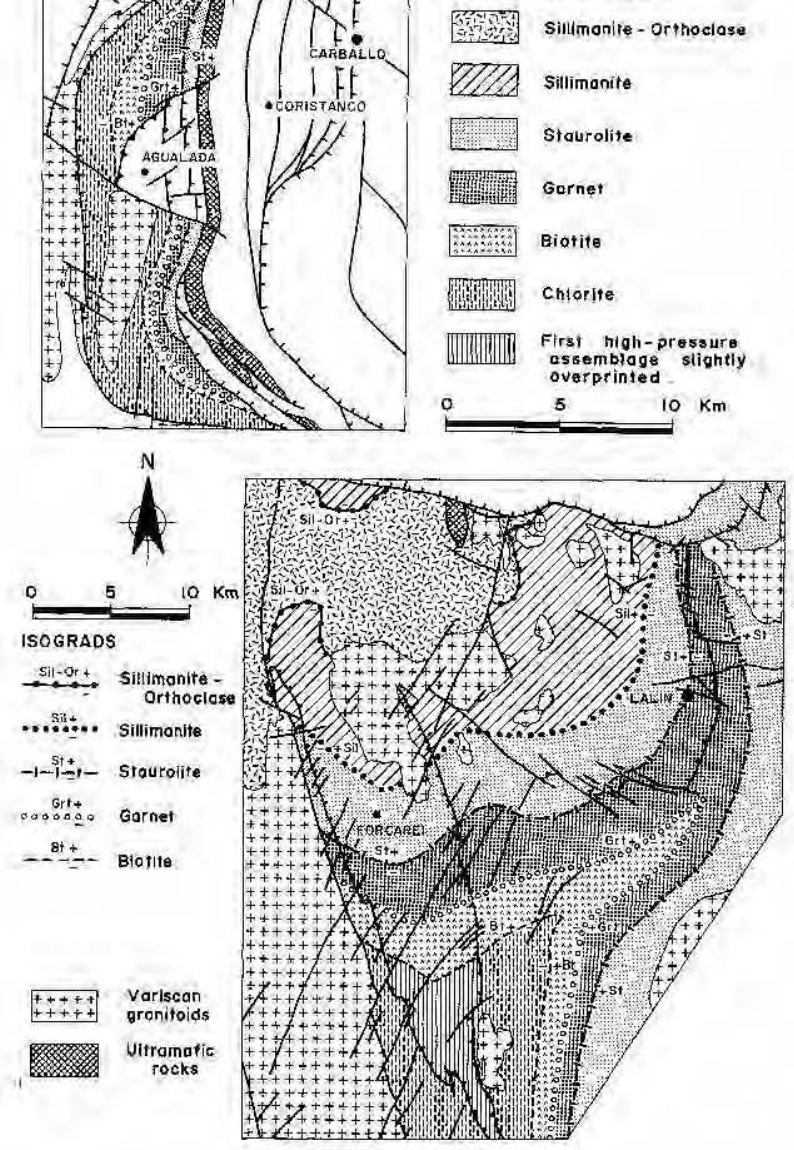

Figure 7. Metamorphic zonation in the basal units of Ordenes, (top) Northern part of the Santiago Unit. (bottom) Lalín and Forcarei Units and the parautochthon.

the ophiolitic unit of Bazar from the Santiago Unit (Figure 6) that shows an inverted metamorphism. However, the BD crosscuts the inverted metamorphic zonation (Figure 7), indicating that this is not the original detachment which carried the Bazar Unit over Santiago. In the orthogneisses of Santiago, kinematic criteria in the regional foliation, which is contemporaneous to the inverted metamorphism [Arenas et al., 1995], suggest a top to the south sense of shear for the original structure.

The Vila de Cruces Detachment (VCD), in the east of Ordenes, underlies the intensely mylonitized ophiolitic unit. Stretching lineation in mylonites and S-C structures indicate a sense of shear to the north or NNE. The VCD does not outcrop in direct contact with the Lalín Unit because the place where this is thought to happen is hidden by the later PSD. The sections B-B' and C-C' of Figure 6 show the suggested relationships between the LFT, VCD and PSD: The LFT is cut by the VCD and both by the PSD. The relationships between the BD and VCD are not seen.

The Pico Sacro Detachment is the later and more continuous detachment in Ordenes. Initially described in the south by $\overrightarrow{V a n}$ Zuuren [1969] and then studied by Marquinez Garcia [1984], it can actually be followed from the Serra do Careón in the SE, to 
the south (Figure 3), west, and NW (Figure 5) until the coast. It shows a consistent top to NW sense of shear. Along its 140 $\mathrm{km}$, there is a metamorphic jump between the high-degree schists, migmatites, and granites of its footwall and the less metamorphic, often low-grade rocks of the hanging wall. Some granites were late enough to pierce the detachment. On petrological grounds, the vertical component of the fault is estimated at around $5 \mathrm{~km}$ [Marquinez Garcia, 1984], and the horizontal one does not exceed two dozen kilometers, because of the assumed initial continuity between the orthogneisses in the north of Lalín and in the south of Santiago. Several smaller normal faults in the hanging wall, in the areas of Pico Sacro and Bembibre, are listric and join the PSD asymptotically (Figures 2, 3, and 5). The detachment was locally reactivated either during or after the subsequent folding.

The PSD crosscuts a set of late, roughly NW-SE upright folds: the Lalín and Forcarei Synforms and the Candán Antiform (Figures 3 and 6). However, it is in turn folded by a younger set of upright folds, striking NS to NE-SW (Figures 4 and 5), that are responsible for the present synformal structure of the Ordenes Complex (excluding the Lalín and Forcarei Units). The NS to NE-SW folds seem to be in relation to transcurrent sinistral shear zones (Figure 2), of which the Palas de Rei Shear Zone (PRSZ) is the most important. Another set of upright folds occurs in the north of Lalin, close to the PSD. They strike roughly E-W and interfere with the N-S set, giving rise to a dome and basin pattern (Figure 4 ). These folds seem linked to the PSD.

An antiform whose orientation varies from N-S to NE-SW limits the western part of the Ordenes Complex. In its west limb, the Malpica-Tui Units (Figures 5 and 6, section E-E') outcrop in the core of a regional synform. Also, the Cabo Ortegal Complex, east of the PRSZ, possesses a synformal character, and an antiform separates it from the PRSZ.

\section{Tectonothermal Evolution of the Basal Units}

All basal units underwent an initial HP metamorphic event whose PT conditions vary according to the position they occupied in the crustal subduction complex. They may be subdivided in two sets: the lower, affected by an initial metamorphism of high $\mathrm{P}$ and low to intermediate T (HP-LIT), and the upper, where the initial metamorphism was of high $\mathrm{P}$ and intermediate to high T (HP-IHT). The relative position of both sets is established in the west of Ordenes, where the Agualada Unit (IHT) is thrust over the Santiago Unit (LIT).

\section{Lower Units With HP-LIT Metamorphism}

A gradient in the metamorphic conditions exists in the Ordenes Complex for the initial event: the PT conditions increase from Forcarei to Santiago, the Lalín Unit showing intermediate values. As the three units are involved in a huge recumbent fold younger than the HP event, the unfolding of the Carrio Anticline would show that Santiago occupied the westernmost position and Forcarei the easternmost one, indicating that both $\mathrm{P}$ and $\mathrm{T}$ increased toward the west.

All units were decompressed after the HP event, with the peculiarity that decompression took place under an inverted metamorphic gradient that resulted in a thermal inversion, first identified in Santiago.

The Santiago Unit. The metamorphic evolution has been studied in the metasediments by Arenas et al. [1995]. Semipelitic schists are characterized by albite porphyroblasts, grown during the first stages of development of the regional foliation, yet during the decompressive events. They include a fine-grained internal schistosity formed by phengitic white mica, chlorite, almandine garnet, epidote, quartz, rutileilmenite, tourmaline, and apatite. Thermobaric determinations in these inclusions suggest temperatures near to $500^{\circ} \mathrm{C}$ and pressures over 15-17 kbar for the HP event.

After this event, the PT path was governed by strong decompression and minor heating. From bottom to top, the metamorphic zones of chlorite, biotite, garnet (second generation), and staurolite developed (Figure 7). The associations with higher $T$ occupy the top of the unit, indicating that the thermal structure is inverted. This feature is not related to the recumbent folding, because the Santiago Unit is the supposed normal limb of the Carrio Anticline. Instead, the decompression took place under an inverted metamorphic gradient, and, considering the narrowness of the metamorphic zones, the thermal gradient was rather high.

The evolution deduced in the metasediments is also recognized in the metabasites. Eclogites included in the orthogneisses show a primary paragenesis with garnet $(\mathrm{Alm}$ C-r $=61-57$ mol\%), omphacite (Jd $\max .=43$ mol\%), quartz, zoisite, and rutile. PT conditions of this paragenesis $(T=$ $515^{\circ}-525^{\circ} \mathrm{C} ; P$ min. $=12 \mathrm{kbar}$ ) are compatible with those of the semipelites for the HP event. The posteclogitic evolution suggests an isothermal or slightly prograde decompression for the lower part of the unit (Figure 8, path E). The decompressive path and the inverted zonation are also recorded by the amphibolites, which include tschermakitic hornblende, albite-oligoclase, and chlorite below and Fe-tschermakite, labradorite, and garnet above.

The Lalín Unit. After the initial HP event, a prograde metamorphism of intermediate to high $\mathrm{T}$ affected the unit, making it difficult to identify the HP assemblages. However, in schists and paragneisses, evidence for the first event is the same as in Santiago: an initial association preserved in plagioclase porphyroblasts. The PT conditions seem to correspond to a garnet-epidote zone. The oldest associations preserved in the metabasites point to the same conclusion. However, the absence of eclogites suggests that the HP event was of lesser grade than in Santiago.

The subsequent decompression was initially prograde, and the metamorphic zonation was again related to an inverted gradient. From bottom to top, the zones of staurolite, sillimanite, and sillimanite-orthoclase developed in metapelites (Figures 7 and 8). In the upper part, the metasediments were partially migmatized, and the muscovite is commonly absent. There, the metabasites are amphibolites without garnet and with late to postkinematic diopsidic clinopyroxene. Plagioclasic veins are common, pointing to a limited partial melting. The metamorphic zones crosscut the Carrio Anticline, and the chronological relationships between mineral growth and deformation support a conductive transmission of heat from above: the staurolite is prekinematic in relation to the main foliation in the 


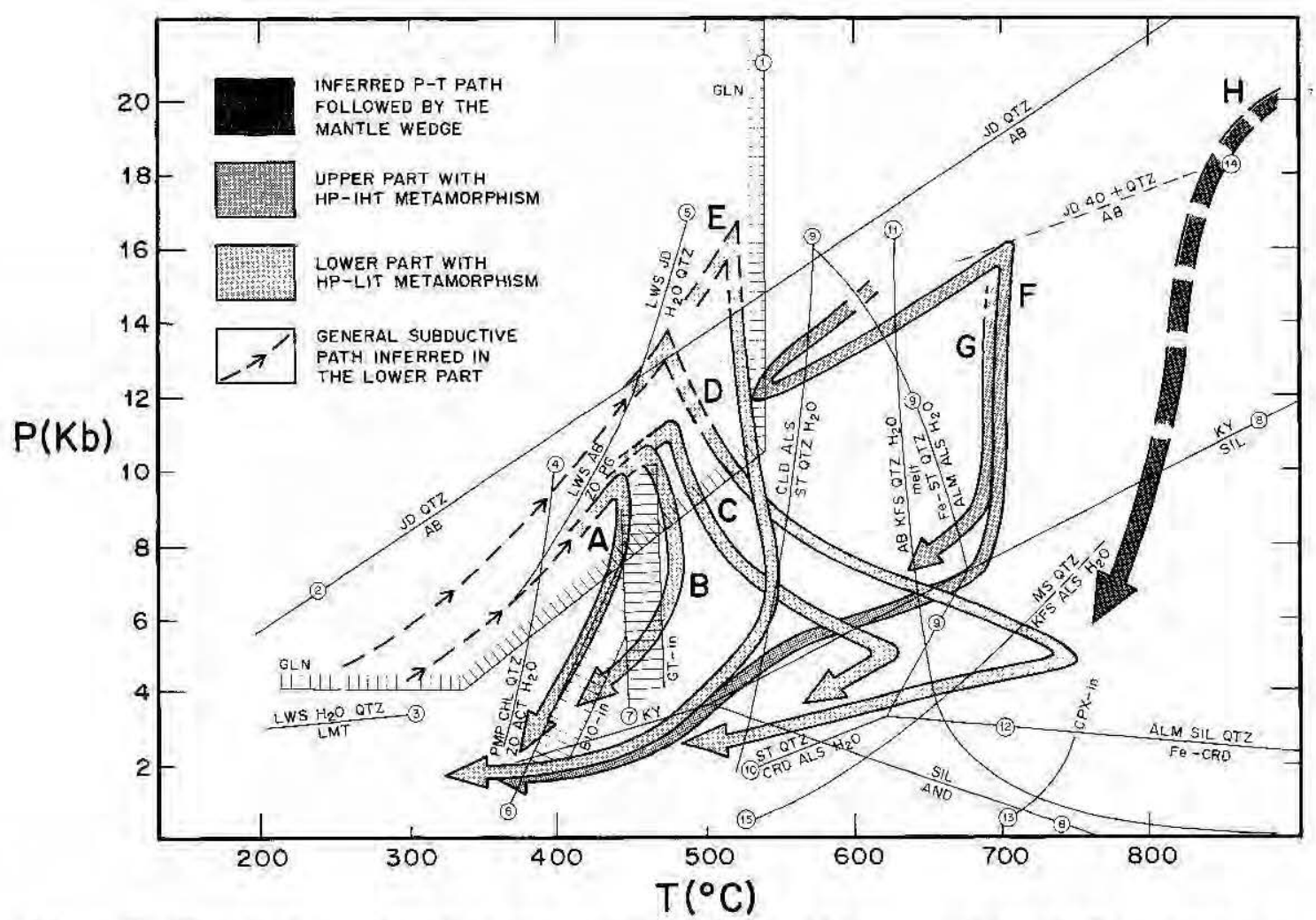

Figure 8. PT paths followed by the basal units: A, basal part of Forcarei in the south; B, garnet zone in Forcarei; C, sillimanite zone in the upper part of Forcarei; D, sillimanite-orthoclase zone in the top of Lalín; E, staurolite zone in Santiago; F, Agualada; G, Espasante; H, probable path for the mantle wedge above the crustal accretionary complex. Reactions: 1, Maresch [1977]; 2, Holland [1980]; 3, Liou [1971]; 4, Schiffman and Liou [1980]; 5, Heinrich and Althaus [1980]; 6, Yardley [1989]; 7, Yardley [1989]; 8, Holdaway [1971]; 9, Richardson [1968]; 10, Rao and Johannes [1979]; 11, Luth et al. [1964]; 12, Holdaway and Lee [1977]; 13, Spear [1981]; 14, Holland [1983]; 15, Chatterjee and Johannes [1974]. Mineral abbreviations after Kretz [1983].

sillimanite zone, being progressively younger downward until the base of the staurolite zone, where it is late to postkinematic. Because the regional foliation transects the Carrio Anticline, the inverted gradient cannot be explained by recumbent folding of a previous normal zonation.

The PT path for the top of the unit (Figure 8, path D) shows a marked prograde decompression, starting from a P peak somewhat less than that of Santiago (path E). The final part of the path entered in the andalusite field. As in Santiago, the decompressive part of the PT path is synkinematic with the main schistosity. This, together with the preservation of associations of the HP-LIT event and of the inverted metamorphic gradient, suggests a quick exhumation.

The Forcarei Unit. The metapelites are fine-grained micaschists with albite porphyroblasts surrounded by the regional schistosity. The porphyroblasts include a very fine to cryptocrystalline, variably microfolded internal schistosity, made up of white mica, chlorite, quartz, ilmeniterutile, and, rarely, garnet. The schistosity in the greenschists facies metabasites locally surrounds rhomboidal polycrystalline aggregates of epidote-clinozoisite, up to 5 $\mathrm{mm}$ in length, which are interpreted as lawsonite pseudomorphs. The HP event is here of lesser $\mathrm{P}$ and $\mathrm{T}$ than in
Santiago and Lalín, being equivalent to the chlorite zone (or the transition chlorite-garnet) of the Sanbagawa Belt [Banno and Sakai, 1989] and to the lawsonite zone of the New Caledonia Belt [Brothers and Yokoyama, 1982]. On the other hand, the assemblages are equivalent to those of the blueschists facies described in the Morais Complex, in Portugal [Munhá et al., 1984; Schermerhorn and Kotsch, 1984].

The subsequent evolution is similar to that of Lalin, but, toward the bottom of Forcarei, two new metamorphic zones of lesser temperature appear related to the regional inverted metamorphism: the garnet and biotite zones (Figures 7 and 8). Underlying the latter is a chlorite zone where HP associations with little reequilibration have been preserved in micaschists (Figure 7). Figure 8 includes the estimated PT paths for the chlorite zone (path A), garnet zone (path B), and sillimanite zone (path C) of the Forcarei Synform. Decompression always took place at a temperature higher than the upper limit of stability of lawsonite, which explains the disappearance of this mineral even in the basal low-T zone.

The Malpica-Tui Units. The HP event is well preserved in the north, near the coast, where high-P and low- $\mathrm{T}$ associations in metapelites and metabasites and several types 
of glaucophane-bearing eclogites have been described [Van der Wegen, 1978; Git Ibarguchi and Ortega Gironés, 1985; Gil Ibarguchi and Arenas, 1990]. The initial event shows eclogitic characteristics, reaching pressures higher than in any other part of the lower set with HP-LIT. This conclusion is sustained by the wide development of the HP associations and also by the mineral assemblages, which include jadeite-bearing parageneses [Gil Ibarguchi, 1995]. These features are compatible with the increase of metamorphic conditions, specially $\mathrm{P}$, toward the west, deduced in the Ordenes Complex.

\section{Upper Units With HP-IHT Metamorphism}

The units of Espasante (Cabo Ortegal) and Agualada (west of Ordenes) consist of migmatitic paragneisses and orthogneisses, amphibolites, and strongly retrograded eclogites, and both underwent an eclogitic metamorphism of similar conditions. However, whereas in Espasante there are no mineral associations permitting the establishment of the PT path previous to the eclogitic peak, the eclogites in Agualada have inclusions which allow the deduction of a complex syneclogitic tectonothermal evolution.

The Espasante Unit. The eclogiles are fine-grained rocks whose primary paragenesis consists of garnet $\left(\mathrm{Alm}_{\mathrm{C}-\mathrm{r}}=\right.$ $51-56 \mathrm{~mol} \% \cdot \operatorname{Prp}_{\mathrm{c}-\mathrm{r}}=11-13 \mathrm{~mol} \%$ ), omphacite (Jd max. $=35$ mol\%), quartz, zoisite, and rutile, equilibrated at $680^{\circ} \mathrm{C}$ and 13 kbar of minimal pressure [Arenas, 1988, 1991]. Several posteclogitic associations indicate an initially decompressive and finally retrograde PT path (Figure 8, path G).

The Agualada Unit. The eclogitic paragenesis consists of garnet (external zone: $\mathrm{Alm}=48 \mathrm{~mol} \%-\operatorname{Prp}=30 \mathrm{~mol} \%$ ), omphacite (Jd $\max .=36 \mathrm{~mol} \%$ ), quartz, zoisite, and rutile, equilibrated at $720^{\circ} \mathrm{C}$ and $15 \mathrm{kbar}$ of minimal P [Abati, 1994]. The garnets depict a discontinuous but well-developed zoning. After an intermediate zone very poor in pyrope content $(\mathrm{Alm}=$ $51 \mathrm{~mol} \%$ - $\mathrm{Prp}=10 \mathrm{~mol} \%)$, they show a core $(\mathrm{Alm}=46 \mathrm{~mol} \%$ $\operatorname{Prp}=16 \mathrm{~mol} \%$ ) with inclusions of a first generation of omphacite ( $\mathrm{Jd} \max .=40 \mathrm{~mol} \%)$. These compositions indicate that the syneclogitic PT path includes a first metamorphic event $\left(T=600^{\circ} \mathrm{C} ; P \min .=13 \mathrm{kbar}\right)$, followed by a slightly decompressive decrease in $\mathrm{T}\left(T=540^{\circ} \mathrm{C} ; P\right.$ min. $\left.=12 \mathrm{~kb}\right)$ which, in turn, was followed by heating and pressurization (Figure 8, path F).

After the eclogitic episode, the PT path, deduced from the paragenetic evolution of metabasites and metapelites, depicts a drastic decompression followed by a slightly decompressive cooling. The metapelites underwent considerable partial melting in the first stages. The final retrogression took place along the lower part of the kyanite stability field and entered the andalusite field.

\section{Metamorphic Evolution of the Footwall Units}

The footwall of the complexes was affected by a metamorphic evolution of Barrovian type or transition to one of lower pressure [Gil Ibarguchi and Arenas, 1990]. It differs strongly from the evolution of the basal units because (1) it does not include HP events; (2) its thermal evolution is usually controlled by normal temperature gradients, though the thermal structure is inverted locally below Lalín and Forcarei; (3) the PT path is opposed and diachronic in relation to that of the HP units, because the footwall units underwent a PT increase while the basal units were being thrust over them.

Below Cabo Ortegal, the progressive sequence includes from top to bottom the zones of chlorite, biotite, garnet and staurolite. The normal zonation is related to the crustal thickening of the orogenic wedge [Arenas, 1991].

Below Lalín and Forcarei, the prograde zones are conditioned by the thermal structure of the allochthon and the heat transferred from above induced an inverted zonation in the upper part of the parautochthon (Figure 7). Furthermore, a normal zonation developed downward. In both cases, the crystallization of garnet and staurolite occurred later than in the allochthon: they are postkinematic with respect to the regional schistosity and postdate thrusting of the Lalín Unit. The repetition of the garnet and staurolite isograds (Figures 6, section A-A', and 7) suggests a thermal transition between a part of the parautochthon governed by an inverted gradient and another dominated by a normal gradient. The preservation of this anomalous thermal structure points to a quick tectonic exhumation.

\section{Structural Evolution, Age Constraints, and Dynamic Implications of the PT History}

The basal units formed part of an accretionary complex created by subduction of the leading edge of the Gondwana margin to the west under a colliding unit consisting, from bottom to top, of a wedge of suboceanic mantle, a stack of ophiolitic units, and a thick tectonic pile which attained eclogitic conditions at its base (Figure 9a). The colliding set was assembled prior to the continental subduction. The eclogitic metamorphism in Cabo Ortegal has been dated at 395 Ma [Schäfer et al., 1993] and the amphibolite facies metamorphism in the ophiolites of Cabo Ortegal and the Portuguese complexes at 390-380 Ma [Peucat et al., 1990; Dallmeyer and Gil lbarguchi, 1990; Dallmeyer et al., 1991].

The polarity of the subduction is indicated by the general sense of shear of the compressional structures [Pérez-Estaún et al., 1991] and by the pressure gradient of the first metamorphic event in the HP-LIT units.

The tectonothermal evolution agrees with the thermal structure of the subduction zones and its temporal variations [Toksöz et al., 1971; Peacock, 1990; Peacock et al., 1994]. The upper set with HP-IHT metamorphism reached the subduction zone first, registering the oldest evolution among the basal units and the bighest $T$, explained by the fact that it encountered the mantle wedge above with its original thermal structure [Peacock, 1990].

The syneclogitic decrease in $\mathrm{T}$ shown by Agualada (Figure 8, path F) may be related to the accretion of a new crustal slice below: the HP-LIT units. The low initial $\mathbf{T}$ of this slice explains the chilling of the previously subducted set according to the models of Davy and Gillet [1986]. After the accretion, both crustal slices were probably subducted altogether, with the Agualada Unit registering a renewed pressurization in its eclogitic path.

In the subduction zone, a migration of the isotherms seems to displace their more depressed part into the new accreted slice, increasing the temperature in the upper slice, as reflected 


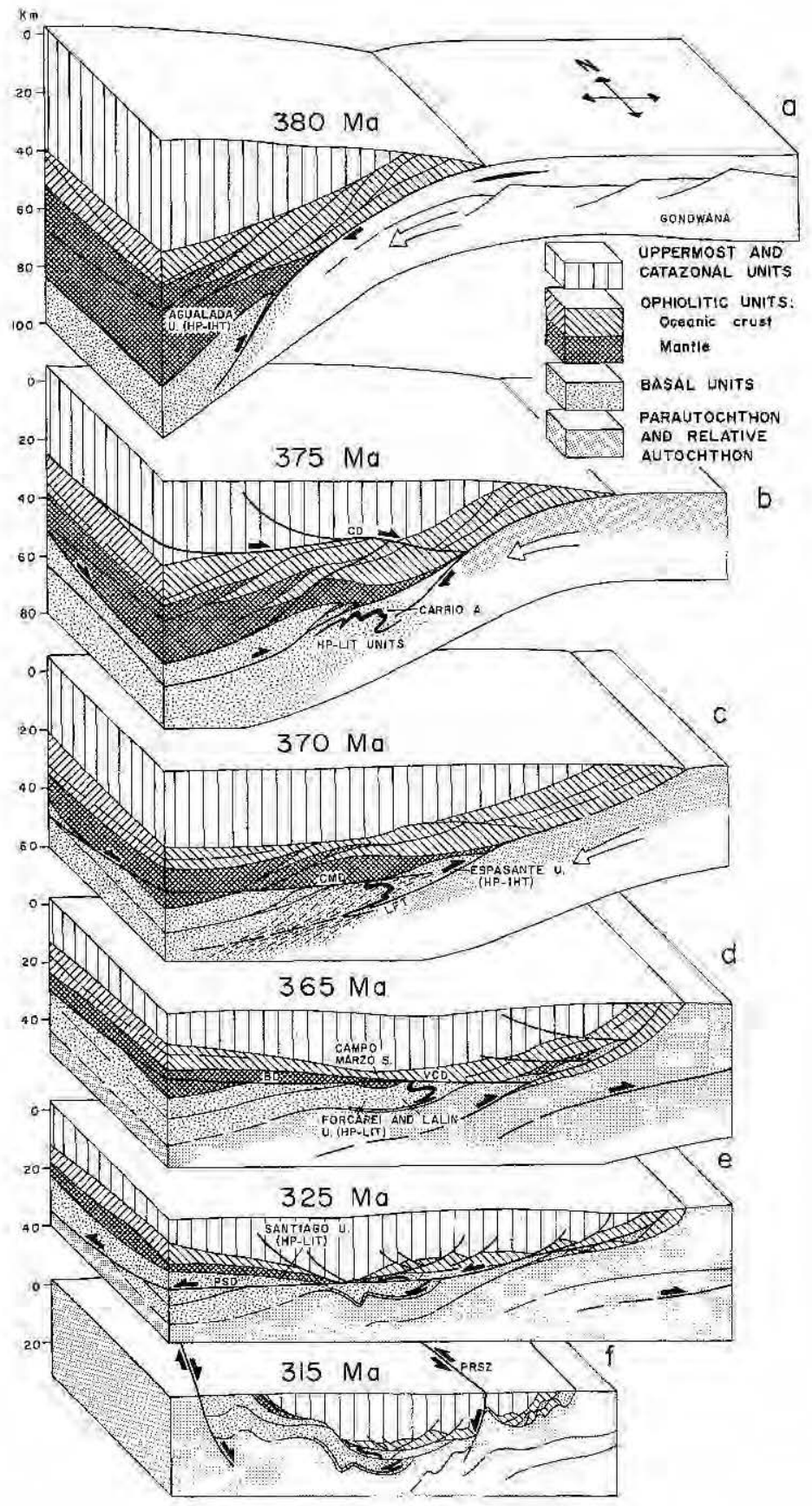

Figure 9. Sketch of the different stages followed by the basal units. (a) Subduction of the Gondwana margin and underthrusting of future high-pressure-low- to intermediate-temperature (HP-LIT) units under previously subducted HP-IHT units. The solid lens represents the Lalín-Forcarei amphibolites. (b) The buoyancy of subducted continental crust triggers the ascent and exhumation, whereas the convergence continues. A south directed normal detachment carries hot ultramafic rocks over the Santiago Unit, giving rise to an inverted metamorphism. Initiation of a new shear zone nucleates the Carrio Anticline. (c) Continued unroofing of the basal units. The CMD induces an inverted metamorphism in Forcarei and Lalín. Contemporaneous development of the transecting foliation in the Carrio Anticline and movement of the LFT is seen. (d) Thinning and tapering of the wedge is allowed by new detachments which crosscut the LFT, while new thrusts affect the parautochthon and the relative autochthon. (e) The later important detachment system, the PSD, develops. (f) Late episode of upright folding and wrench faulting. 
in the path of Agualada, which remained close to the mantle. Furthermore, the accretion induced a generalized chilling of the zone. This and the position under another crustal slice and not under the mantle wedge explain the lesser temperature of the first event in the HP-LIT units.

The final stages of the subduction of the HP-LIT units may be situated $374 \mathrm{Ma}$ ago, age of the immediately posteclogitic white micas in Malpica-Tui [Van Calsteren et,al., 1979]. This is also the age of the Corredoiras Detachment [Dallmeyer et al, 1993], which separates the uppermost and catazonal units in the east of Ordenes. This suggests that extensional structures developed in the upper parts of the orogenic wedge, whereas convergence continued at depth.

A new shear zone nucleated the Carrio Anticline and began the underthrusting of a new slice (Figure 9b). Subsequent underthrusting of more continental material probably blocked the subduction, and buoyancy forces provoked the ascent and exhumation of the basal units.

Decompression took place under an inverted temperature gradient in the basal units. Its possible cause is the development of normal detachments (Figures 9b and 9c) because there is an important baric gap between the basal units and the overlying ophiolitic units [Arenas et al., 1995]. The gap, estimated in more than 6 kbar in the west of Ordenes, may correspond to the portion of the mantle wedge removed. The detachments would have carried a portion of the subophiolitic hot mantle over the basal units, inducing a heating from the top.

The regional foliation in the HP-LIT units is related to a crustal shear zone several kilometers wide which culminated in the $\mathrm{LFT}$, interpreted as a thrust because high-P rocks lay over low-P rocks. However, this foliation registered the inverted metamorphism. For that reason, we postulate a synchronism between compressional and extensional structures. Furthermore, as the pressures in the parautochthon are not subductive, the thrusting is considered contemporaneous with a pronounced thinning of the orogenic wedge above, facilitated by the development of the normal detachments. Dismembering and dispersion of the HP-IHT units could have started at this stage (Figure 9c).

Once subduction was blocked, deformation became intracontinental and progressed toward the external parts of the orogen. Continuous thinning of the wedge was made possible by new detachments (Figure 9d), interpreted as normal based on baric gaps, but the picture is probably much more complicated because thrusting also occurred. The age of 365 Ma obtained by Dallmeyer et al. [1993] in greenschists facies mylonites overlying the basal unit of Espasante, in Cabo Ortegal, suggests that much of the decompression occurred in about $10 \mathrm{Ma}$.

The PSD represents the latest normal detachment system (Figure 9e). It cuts the granodiorites of Negreira, in the west (Figure 5), and Chantada-Taboada, in the east (Palas de Rei, Figure 2), dated at $350 \pm 11 \mathrm{Ma}$ and $323 \pm 11$, respectively [Bellido et al., 1992]. The PSD was preceded but also overprinted by episodes of upright folding and related transcurrent shear zones (Figure 9f), pointing to alternating between compressional and extensional structures even in the late orogenic stages. The age of the latest folds is $314 \pm 6 \mathrm{Ma}$ [Capdevila and Vialette, 1970] (corrected by Ries [1979]).

\section{Conclusions}

The high-P metamorphic event identified in the basal units reflects the subduction of the rifted passive margin of Gondwana toward the west under a colliding element built in the early stages of the Variscan deformation.

Buoyancy forces exerted by the accretion of new continental slices probably induced the ascent and exhumation of the subducted units, whereas the convergence continued. Compressional and extensional structures developed simultaneously and alternated along a time span of around 60 $\mathrm{Ma}$, which corresponds to the intracontinental collisional stage. However, most of the unroofing occurred in the $10 \mathrm{Ma}$ following the end of the subduction.

The abundance of normal detachments indicates that erosional denudation was not effective enough to account for the ascent rates imposed. The detachments show often movement components parallel to the orogenic trend, either to the north or south, a feature that seems also characteristic of the relative autochthon [Escuder Viruete et al., 1994; Díez Balda et al., 1995]. The thinning and tapering of the orogenic wedge and its lateral spreading reflect the squeezing of huge volumes of rocks, induced by the gravity-driven vertical

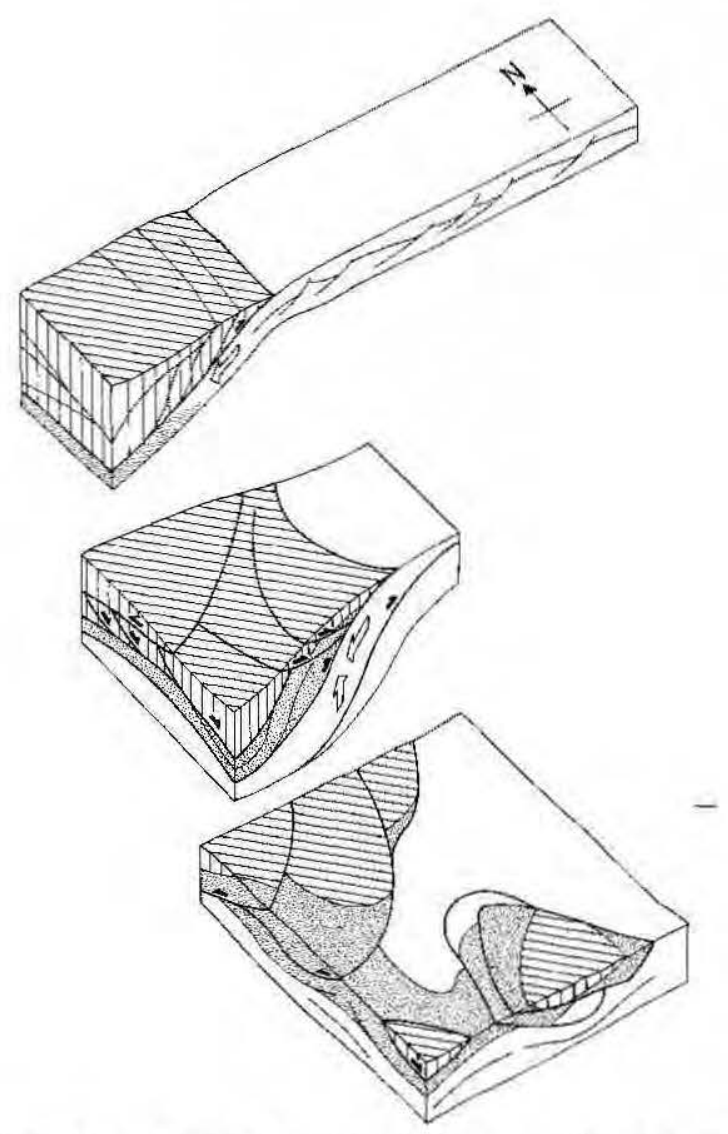

Figure 10. Proposed evolution showing the change in deformational regime from subductive to intracontinental and the accompanying crustal thinning and spreading allowed by several generations of normal detachments. Ruled area indicates ophiolites, catazonal and uppermost units; dotted area indicates basal units. 
shortening and accomplished by the detachments and, probably, also by coaxial ductile deformations. The present geometry of the allochthonous complexes and the dispersion of their units may be explained by these mechanisms (Figure 10).

The Ordenes Complex offers a regional framework to study the dynamic evolution of orogenic wedges and the thermal evolution of subduction zones and shows the role that the mantle wedge above the subducted margin may play in the whole dynamics. This wedge may account for the development of regional metamorphic inversions during the exhumation of the subducted ensembles.

Acknowledgments. This study was financed by project PB91-0192-C02 of the DGICYT (Spain). Thanks are given to J.P. Burg and P. Matte for constructive review. The help of Barbara Knowles with the English version is kindly acknowledged.

\section{References}

Abati, J., Evolución tectonotermal de las eclogitas de la Unidad de Agualada (Complejo de Ordenes, NW del Macizo Ibérico), Ms, thesis, Univ. Complutense, Madrid, 1994.

Arenas, R., Evolución petrológica y geoquímica de la unidad alóctona inferior del complejo metamórfico básicoultrabásico de Cabo Ortegal (Unidad de Moeche) y del Silúrico paraautóctono, Cadena Hercínica Ibérica (NW de España), Corpus Geol. Gallaeciae, 4, 1988.

Arenas, R., Opposite P,T,t paths of Hercynian metamorphism between the upper units of the Cabo Ortegal Complex and their substratum (northwest of the Iberian Massif), Tectonophysics, 191, 347-364, 1991.

Arenas, R., J.I. Gil-lbarguchi, F. GonzálezLodeiro, E. Klein, J.R. Martínez-Catalán, E. Ortega-Girones, J.G. de Pablo-Maciá, and M. Peinado, Tectonostratigraphic units in the complexes with mafic and related rocks of the NW of the Iberian Massif, Hercynica, $I I, 87-110,1986$.

Arenas, R., F.J. Rubio Pascual, F. Díaz García, and J.R. Martínez Catalán, High-pressure micro-inclusions and development of an inverted metamorphic gradient in the Santiago Schists (Ordenes Complex, NW Iberian Massif, Spain): Evidence of subduction and syn-collisional decompression, J. Metamorph. Geol, 13, 141-164, 1995.

Banno, S., and C. Sakai, Geology and metamorphic evolution of the Sanbagawa metamorphic belt, Japan, in Evolution of Metamorphic Belts, edited by J.S. Daly, R.A. Cliff, and B.W.D. Yardley, Geol. Soc. Spec. Publ. London, 43, 519-532, 1989.

Bellido, F., J.L. Brandle, M. Lasala, and J. Reyes, Consideraciones petrológicas y cronológicas sobre las rocas graniticas hercínicas de Galicia, Cuad, Lab. Xeol. Laxe, 17, 241-261, 1992.

Bernard-Griffiths, J., J.J. Peucat, J. Cornichet, M. Iglesias Ponce de León, and J.I. Gil Ibarguchi, U-Pb, Nd isotope and REE geochemistry in eclogites from the Cabo Ortegal Complex, Galicia, Spain: An example of REE immobility conserving MORB-like patterns during high-grade metamorphism, Chem. Geol., 52, 217-225, 1985.

Blaise, J, and E. Bouyx, Les séries cambroordoviciennes à Cruziana et le problème de l'extension septentrionale des plate-formes "perigondwaniennes" durant le Paléozoïque inféricur, C.R. Acad. Sci, Ser, D, 291, 793796, 1980.

Brothers, R,N., and K. Yokoyama, Comparison of high pressure schist belts of New Caledonia and Sanbagawa, Japan, Contrib. Mineral. Petrol., 79, 219-229, 1982.

Capdevila, R., and Y. Vialette, Estimation radiométrique de l'âge de la deuxième phase tectonique hercynienne en Galice moyenne (Nord-Ouest de l'Espagne), C.R. Acad. Sci.,Ser. D, 270, 2527-2530, 1970.

Chatterjee, N.D., and W. Johannes, Thermal stability and standard thermodynamic properties of synthetic $2 \mathrm{M}_{1}$-muscovite $\left(\mathrm{KAl}_{2}\left(\mathrm{AlSi}_{3} \mathrm{O}_{10}(\mathrm{OH})_{2}\right)\right.$, Contrib. Mineral. Petrol., 48, 89-114, 1974.

Dallmeyer, R.D., and J.I. Gil Ibarguchi, Age of amphibolitic metamorphism in the ophiolitic unit of the Morais allochthon (Portugal): Implications for early Hercynian orogenesis in the Iberian Massif, J. Geol. Soc: London, 147, 873-878, 1990.

Dallmeyer, R.D,. and R.D. Tucker, U-Pb zircon age for the Lagoa augen gneiss, Morais Complex, Portugal: Tectonic implications, J. Geot. Soc. London, 150 , 405-410, 1993.

Dallmeyer, R.D., A. Ribeiro, and F. Marques, Polyphase Variscan emplacement of exotic terranes (Morais and Bragança Massifs) onto Iberian successions: Evidence from ${ }^{40} \mathrm{Ar} /{ }^{39} \mathrm{Ar}$ mineral ages, Lithos, 27,133 144, 1991.

Dallmeyer, R.D., J.R. Martínez Catalân, R. Arenas, 3.1. Gil Ibarguchi, P. Gervas, P. Farias, J. Aller, F, Bastida, and G. Gutiérrez Alonso, ${ }^{40} \mathrm{Ar} / 39 \mathrm{Ar}$ dating of mylonites in the allochthonous complexes of NW Spain, Terra Abstr., 5(1), 384, 1993.

Davy, P., and P. Gillet, The stacking of thrust slices in collision zones and its thermal consequences, Tectonics, 5, 913-929, 1986.

Díaz García, F., La Unidad de Agualada, Borde W del Complejo de Ordenes (NW de España), Trab. Geol., 16, 3-14, 1986.

Díaz García, F., La geología del sector occidental del Complejo de Ordenes (Cordillera Hercínica, NW de España), Nova Terra, 3, 1990.

Díaz García, F., Propuesta de una nueva zona en el Hercínico de la Península Ibérica, Cuad. Lab. Xeol, Laxe, 17, 199-207, 1992.

Díaz García, F., Análisis comparativo de la foliación regional y estructuras asociadas en el Dominio de Santiago y su autóctono relativo (Galicia, NW de España), Rev. Soc. Geol. Esp., 6, 105-114, 1993.

Díez Balda, M.A., J.R. Martínez Catalán, and P. Ayarza, Syn-collisional extensional collapse parallel to the orogenic trend in a domain of steep tectonics: The South of Salamanca detachment zone (Central Iberian Zone, Spain), J. Struct. Geol., 17, 163-182, 1995.

Escuder Viruete, J., R. Arenas, and J.R. Martínez Catalán, Tectonothermal evolution associated with Variscan crustal extension in the Tormes Gneiss Dome (NW Salamanca, Ibcrian Massif, Spain), Tectonophysics, 238, 117-138, 1994.

Farias, P., G. Gallastegui, F. GonzálezLodeiro, J. Marquínez, L.M. Martín-Parra, J.R. Martínez-Catalán, J.G. de PabloMaciá, and L.R. Rodríguez-Fernández, Aportaciones al conocimiento de la litoestratigraffa y estructura de Galicia Central, Mem. Fac. Ciênc. Univ. Porto, 1 , 411-431, 1987.

Floor, P., Petrology of an aegirine-riebeckite gneiss-bearing part of the Hesperian Massif: The Galineiro and sourrounding areas, Vigo, Spain, Leidse Geol. Meded., 36, 1-203, 1966 .

Fombella Blanco, M.A., Age palynologique du blastomilonitic Grabben, Zone Occidentale de la Galice, Rev.Micropaléontol., 27, 113117, 1984.

García Garzón, J., J.G. de Pablo Maciá, and J.F. Llamas Borrajo, Edades absolutas obtenidas mediante el método $\mathrm{Rb} / \mathrm{Sr}$ en dos cuerpos de ortoneises en Galicia Occidental, Bol. Geol. Min. Esp. 92, 463466, 1981.

Gil Ibarguchi, J.I., Petrology of jadeite metagranite and associated orthogneiss from the Malpica-Tuy allochthon (Northwest Spain), Eur. J. Mineral., 7, 403$415,1995$. 
Gil Ibarguchi, J.I., and R. Arenas, Metamorphic evolution of the Allochthonous Complexes from the Northwest of the Iberian Peninsula, in PreMesozoic Geology of Iberia, edited by R.D. Dallmeyer and E. Martínez García, pp. 237-246, Springer-Verlag, New York, 1990.

Gil Ibarguchi, J.I., and E. Ortega Gironés, Petrology, structure and geotectonic implications of glaucophane-bearing eclogites and related rocks from the Malpica-Tuy (MT) Unit, Galicia, Northwest Spain, Chem. Geol., 50, 145-162, 1985.

Girardeau, J., and J.I, Gil Ibarguchi, Pyroxenite-rich peridotites of the Cabo Ortegal Complex (Northwestern Spain): Evidence for large-scale upper-mantle heterogeneity, J. Petrol, 32, (Spec. Lherzolites Issue), 135-154, 1991.

Heinrich, W., and E. Althaus, Die obere stabilitats grenze von Lawsonit plus Albit bzw. Jadeit, Fortschr.Mineral., 58, 49-50, 1980.

Hilgen, J.D., The Lalín Unit: a new structural element in the Hercynian Orogen of Galicia (NW Spain), Proc. K. Ned. Akad. Wet. Ser. B Palaeontol. Geol. Phys. Chem., 74, 398-407, 1971.

Holdaway, M.J, Stability of andalusite and the aluminum silicate phase diagram, Am. J. Sci., 271, 97-131, 1971.

Holdaway, M.J., and S.M. Lee, Fe-Mg cordierite stability in high grade pelitic rocks based on experimental, theoretical and natural observations, Contrib. Mineral. Petrol., 63, 175-198, 1977.

Holland, T.J.B., The reaction albite $=$ jadeite + quartz determined experimentally in the range $600-1200^{\circ} \mathrm{C}$, Am. Mineral., 65,129 $134,1980$.

Holland, T.J.B., The experimental determination of activities in disordered and short-range ordered jadeitic pyroxene, Contrib. Mineral, Petrol., 82, 214-220, 1983.

Kretz, R,, Symbols for rock-forming minerals, Am. Mineral., 68, 277-279, 1983.

Kuijper, R.P., U-Pb systematics and the petrogenetic evolution of infracrustal rocks in the Paleozoic basement of Western Galicia, NW Spain, Verh. ZWO Lab. Isot. Geol. Amsterdam, 5, 1-101, 1979.

Liou, J.G., P - T stabilities of laumontite, wairakite, lawsonite and related minerals in the system $\mathrm{CaAl}_{2} \mathrm{Si}_{2} \mathrm{O}_{8}-\mathrm{SiO}_{2}-\mathrm{H}_{2} \mathrm{O}, J$, Petrol., 12, 379-411, 1971.

Luth, W.D., R.H. Jahus, and O.F. Tuttle, The granite system at pressures of 4 to 10 kilobars, J. Geophys. Res., 69, 659-773, 1964.

Maaskant, P., Chemical petrology of polymetamorphic ultramafic rocks from Galicia, NW Spain, Leidse Geol. Meded., 45, 237-325, 1970.
Marcos, A., J. Marquínez, A. Pérez-Estaún, J.A. Pulgar, and F. Bastida, Nuevas aportaciones al conocimiento de la evolución tectonometamórfica del Complejo de Cabo Ortegal (NW de España), Cuad. Lab. Xeol. Laxe, 7, 125-137, 1984.

Maresch, W.V., Experimental studies of glaucophane: An analysis of present knowledge, Tectonophysics, 43, $109-125$, 1977.

Marquínez García, J.L., La geología del área esquistosa de Galicia Central (Cordillera Herciniana, NW de España), Mem. Inst. Geol. Min. Esp., 100, 1984.

Martínez Catalán, J.R., A non-cylindrical model for the northwest Iberian allochthonous terranes and their equivalents in the Hercynian belt of Western Europe, Tectonophysics, 179, 253-272, 1990.

Martínez Catalán, J.R., and R. Arenas, Deformación extensional de las unidades alóctonas superiores de la parte oriental del Complejo de Ordenes (Galicia), Geogaceta, 11, 108-111, 1992.

Martínez Catalấn, J.R., E. Klein, J.G. de PabloMaciá, and F. González Lodeiro, El Complejo de Ordenes: Subdivisión, descripción y discusión sobre su origen, Cuad. Lab. Xeol. Laxe, 7, 139-210, 1984.

Munhá, J., A. Ribeiro, and M.L. Ribeiro, Blueschists in the Iberian Variscan Chain (Trás-os-Montes: NE Portugal), Com. Serv. Geol. Port., 70, 31-53, 1984.

Peacock, S.M., Numerical simulation of metamorphic pressure-temperature-time paths and fluîd production in subducting slabs, Tectonics, 9, 1197-1211, 1990.

Peacock, S.M., T. Rushmer, and A.B. Thompson, Partial melting of subducting oceanic crust, Earth Planet. Sci. Leti., 121, 227-244, 1994.

Pérez-Estaún, A., J.R. Martínez Catalán, and F. Bastida, Crustal thickening and deformation sequence in the footwall to the suture of the Variscan Belt of NW Spain, Tectonophysics, 191, 243-253, 1991.

Peucat, J.J., J. Bernard-Griffiths, J.L. Gil Ibarguchi, R.D. Dallmeyer, R.P. Menot, J. Cornichet, and M. Iglesias Ponce de León, Geochemical and geochronological cross section of the deep Variscan crust: The Cabo Ortegal high-pressure nappe (northwestern Spain), Tectonophysics, 177 , 263-292, 1990.

Platt, J.P., Dynamics of orogenic wedges and the uplift of high-pressure metamorphic rocks, Geot. Soc, Am. Bull., 97, 1037-1053, 1986.

Rao, B.B., and W. Johannes, Further data on the stability of staurolite, Neues Jahrb. Mineral. Monatsh., 10, 437-447, 1979.

Ribeito, A, E. Pereira, and R. Dias, CentralIberian Zone. Allochthonous sequences. Structure in the northwest of the lberian Peninsula, in Pre-Mesozoic geology of
Iheria, edited by R.D. Dallmeyer and E. Martínez García, pp. 220-236, SpringerVerlag, New York, 1990.

Richardson, S.W., Staurolite stability in a part of the system Fe-AI-Si-O-H, J. Petrol., 9, $467-488,1968$.

Ries, A.C., Variscan metamorphism and $\mathrm{K}-\mathrm{Ar}$ dates in the Variscan fold belt of S Brittany and NW Spain, J. Geol. Soc. London, 136, 89-103, 1979.

Santos Zalduegui, J.F., U. Schärer, and J.I. Gil lbarguchi, Isotope constraints on the age and origin of magmatism and metanorphism in the Malpica-Tuy allochthon, Galicia, NW-Spain, Chem. Geol., 121, 91-103, 1995.

Schäfer, H.J., D. Gebauer, J.I. Gil Ibarguchi, and J.I. Peucat, Ion-microprobe U-Pb zircon dating on the HP/HT Cabo Ortegal Complex (Galicia, NW Spain): preliminary results, Terra Abstr., 5(4), 22, 1993.

Schermerhorn, L.J.G., and S. Kotsch, First occurrence of lawsonite in Portugal and tectonic implications, Com. Serv, Geol. Port., 70, 23-29, 1984.

Schiffman, P., and J.G. Liou, Synthesis and stability relations of $\mathrm{Mg}-\mathrm{Al}$ pumpellyte, $\mathrm{Ca}_{4} \mathrm{Al}_{5} \mathrm{MgSi}_{6} \mathrm{O}_{21}(\mathrm{OH})_{7}, J$. Petrol., 21 , 441-474, 1980.

Spear, F.S., An experimental study of hornblende stability and compositional variability in amphibolite, Am. J. Sci., 281, 697-734, 1981 .

Toksöz, M.N., J,W, Minear, and B.R. Julian, Temperature field and geophysical effects of a down-going slab, J. Geophys. Res., 76, 1113-1138, 1971.

Van Calsteren, P.W.C, N.A.I.M. Boelrijk, E.H. Hebeda, H.N.A. Priem, E. Den Tex, E.A.T.H. Verdurmen, and R.H. Verschure, Isotopic dating of older elements (including the Cabo Ortegal mafic-ultramafic complex) in the Hercynian Orogen of NW Spain: Manifestations of a presumed Early Paleozoic Mantle-plume, Chem. Geol. 24, 35-56, 1979.

Van der Wegen, G., Garnet-bearing metabasites from the Blastomylonitic Graben, Western Galicia, Spain, Scr. Geol., 45, 1-95, 1978.

Van Zuuren, A., Structural petrology of an area near Santiago de Compostela (NW Spain), Leidse Geol. Meded., 45, 1-71, 1969.

Vogel, D.E., Petrology of an eclogite -and pyrigarnite- bearing polymetamorphic rock Complex at Cabo Ottegal, NW Spain, Leidse Geol. Meded, 40, 121-213, 1967.

Warnaars, F.W., Petrology of a peritotiteamphibolite and gabbro-bearing polyorogenic terrain NW of Santiago de Compostela (Spain), Ph.D. thesis, Univ. Leiden, Holland, 1967.

Yardley, B.W.D., An introduction to Metamorphic Petrology, Longman Sci. and Tech., Essex, 1989. 
J. Abati and R. Arenas, Departamento de Petrología y Geoquímica, Universidad Complutense, 28040-Madrid, Spain.

F. Díaz García and J. Marquínez, Departamento de Geología, Universidad de Oviedo, 33005-
Oviedo, Spain. (e-mail: floro@ asturias.geol.uniovi.es)

J. R. Martínez Catalán, Departamento de Geología, Universidad de Salamanca, 37008Salamanca, Spain. (e-mail: jrmc@gugu.usal.es)

F. J. Rubio Pascual, Instituto Tecnológico
Geominero de España, Rios Rosas 23, 28003Madrid, Spain. 